\title{
Immediate and long-term effects of invasive plant species on soil characteristics
}

\author{
Irene M. Unger ${ }^{1,{ }^{*}}$, Robert J. Kremer ${ }^{2}$, Kristen S. Veum ${ }^{3}$, Keith W. Goyne ${ }^{4}$ \\ 1 Department of Biology and Chemistry, Baker University, P.O. Box 65, Baldwin City, KS 66006, USA \\ 2 School of Natural Resources University of Missouri, 302 ABNR Bldg., Columbia, MO 65211, USA \\ 3 USDA-ARS, Cropping Systems and Water Quality Unit, University of Missouri, 302 ABNR Bldg. Columbia, MO 65211, USA \\ 4 Department of Forest Resources and Environmental Conservation, Virginia Tech, 324 Cheatham Hall, Blacksburg, VA 24061, USA
}

\section{H I G H L I G H T S}

- Infestations of Lespedeza cuneata alter soil microbial communities and their actions.

- Soil alterations persisted up to four years after eradication verses a native prairie.

- Presence of prairie vegetation may not reflect soil microbial recovery from infestation.

- Legacy effects of invasives may result in protracted impacts on soil microorganisms.

- Monitoring soil health indicators in prairies undergoing rehabilitation is important.

\section{ARTICLE INFO}

Article history:

Received February 3, 2021

Revised May 13, 2021

Accepted May 19, 2021

Keywords:

Sericea lespedeza

Legacy effects

Soil microorganisms

\section{GRAPHICAL ABSTRACT}

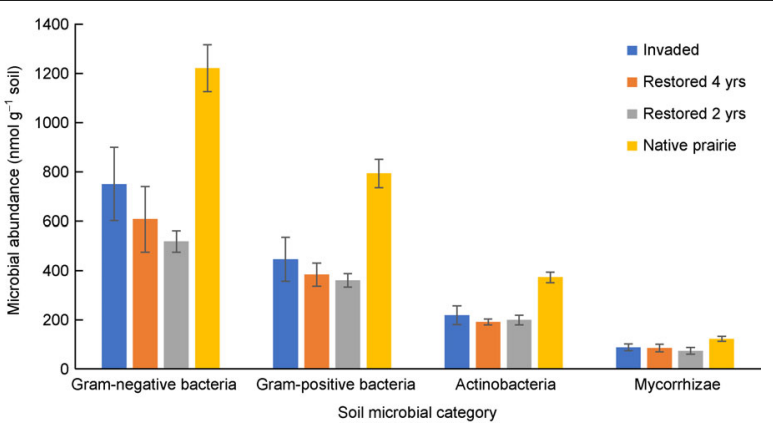

A B S T R A C T

Invasive plant species may alter soil characteristics or interact with the soil microbial community resulting in a competitive advantage. Our objectives were to determine: i) if invasive plant species alter soil properties; and ii) the long-term effects of invasive plant species on soil properties and subsequent implications on ecological restoration efforts. We focused on Lespedeza cuneata, a plant that may be allelopathic. Soil samples were collected from four locations in Central Missouri, USA: an old-field with abundant $L$. cuneata, two reconstructed sites, and a remnant prairie that has never been plowed. Soil health indictors were used to characterize soil properties at these sites. Nearly every soil property differed significantly between the unplowed prairie reference site and the other three sites. The reconstructed sites, however, generally did not differ from the invaded old-field. These results indicate that the reconstructed prairies are not fully recovered. Although above-ground traits, such as the plant community structure, appear similar to the prairie, the soil microbial community structure still resembles that of an invaded old-field site. These results indicate that more time may be needed before soil microbial populations fully recover after invasive plant removal.

(c) Higher Education Press 2021
* Corresponding author

E-mail address: iunger@bakeru.edu (I.M. Unger)

\section{Introduction}

Research focused on invasive plant species has primarily involved studying traits associated with the invading organism and impacts to the above ground ecology. It is now widely known that there are many factors or attributes that contribute to a species' "invasiveness." Among these are phenotypic plasticity, high intrinsic rate of natural increase, 
competitive ability, and vegetative reproduction. In terms of competitive ability, the species in question might inherently utilize resources better than native species or they might successfully transform environmental conditions such as soil characteristics in the introduced habitat.

Interactions between invasive plants and the soil microbial community may contribute to invasive species advantages over native species. Studies have shown that the soil microbial community does indeed respond to changes in vegetation (Kennedy, 1999; Buyer et al., 2002; Ibekwe et al., 2002; Mungai et al., 2005; Dornbush, 2007; Macdonald et al., 2009; Yannarell et al., 2011; Unger et al., 2012) including the introduction of invasive species (Kourtev et al., 2002; Kourtev et al., 2003; Chacón et al., 2009). The invasive species may, for example, through its root exudates stimulate the soil microbial community and thereby benefit from increased nutrient cycling (Ehrenfeld, 2003; Wolfe and Klironomos, 2005; Koutika et al., 2007; Niu et al., 2007; Kao-Kniffin and Balser, 2008, Waller et al., 2020). Or similarly, the soil microbial community may alter allelopathic chemicals released by the invasive plant making them more (or less) toxic to nearby vegetation (Inderjit, 2005; Lankau, 2010). On the other hand, invasive species may benefit by escaping the constraints placed on them by soil microbes in their native range (i.e., enemy-release hypothesis) (Niu et al., 2007; Inderjit and van der Putten, 2010; Schradin and Cipollini, 2012).

Lespedeza cuneata (the focus of this study) was introduced in Missouri in the 1930s (Eddy et al., 2003). Early investigations by the Agricultural Experimental Station at the University of Missouri demonstrate the extensive rooting ability of this long-lived perennial legume, noting that "a good stand should last indefinitely" (Helm and Etheridge, 1933). Root characteristics of $L$. cuneata contribute to its ability to withstand drought and tolerate low fertility soils (Helm and Etheridge, 1933), and, as such, to its ability to thrive under a variety of environmental conditions (Cummings et al., 2017). While utilization of $L$. cuneata for hay or pasture was promoted, its high tannic content and thus lower palatability than other forage crops were noted as early as 1933 by Helm and Etheridge. In addition to use as a forage crop, $L$. cuneata was planted for erosion control along highways and other roadways as well as on strip-mined land (Eddy et al., 2003). Widespread planting along with $L$. cuneata's superior competitive ability and lack of disease and insect control, contribute to its status as an invasive and noxious weed (Cummings et al., 2017).

L. cuneata, as a suspected allelopathic plant, may also alter soil conditions to its advantage. Analysis of vegetative residues from $L$. cuneata detected phenolic compounds such as protocatechuic acid, vanillin, ferulic acid and pcoumaric acid (Langdale and Giddens, 1967). Subsequent bioassays with these extracts inhibited the growth of Avena sativa leading the authors to suggest that these phenolic compounds contributed to the observed inhibition (Langdale and Giddens, 1967). Grass species varied in their response to root exudates from $L$. cuneata with some showing reduced germination and others reduced radicle and coleoptile length and overall biomass (Kalburtji and Mosjidis, 1993; Dudley and Fick, 2003). While the response of agricultural (Kalburtji and Mosjidis 1993) and native grasses (Dudley and Fick, 2003) have been tested for response to $L$. cuneata residues, it is not known if other prairie species have been investigated. However, invasion of $L$. cuneata does seem to affect the soil microbial community structure. Sites heavily invaded with $L$. cuneata had significantly different soil bacterial communities (but not soil fungi communities) than non-invaded sites (Yannarell et al., 2011). The distinctive responses of the soil bacterial and fungi communities suggest different ecological roles for these microbial groups in the invasion process (Yannarell et al., 2011).

It is unclear how long plant-mediated changes in soil biological, chemical, and physical properties may persist. Given the short generation time of bacteria (i.e., bacteria under ideal conditions can reproduce every 20-30 min), the soil microbial community may be able to respond quickly to changes; however, legacy effects may be possible. Shifts in soil microbial community structure with vegetation changes under greenhouse conditions have occurred in little as two years (Elgersma et al., 2011). However, under field conditions similar shifts were not observed within this time frame (Elgersma et al., 2011). The authors conclude that killing or removing above ground vegetation without the removal of roots or rhizomes of invasive plants may thwart ecological restoration efforts by continued influence on the soil microbial community (Elgersma et al., 2011). It is not known if $L$. cuneata is capable of such an effect.

Soil-microbe mediated plant interactions play a role in community structure and function; therefore, it seems likely that these interactions also play a role in restoration efforts. For example, restored tallgrass prairie soils in Wisconsin developed higher abundances of arbuscular mycorrhizae and rhizosphere-associated bacteria compared with paired cultivated soils (Mackelprang et al., 2018), suggesting that these microbial communities and their interactions with prairie plant species are critical in successful restoration. What is challenging is the variability of the response. One study might indicate positive effects (e.g., enhanced microbial biomass correlated with increased plant biomass and/or productivity) while another, similar study, shows negative results, and a third no net response. In addition, different systems within a study may have different responses. Mackelprang et al. (2018) observed that the mycorrhizae association with warm season grass roots was considerably higher than for cultivated crops while bacteria abundance was somewhat intermediate between the restored prairie soils and cultivated soils. And, as noted above, soil bacterial communities and soil fungi communities may respond differently to invasive species (Yannarell et al., 2011). It is difficult to make broad sweeping generalizations and, thus, specific systems must be studied. Mackelprang et al. (2018) noted the complexity of the soil microbial community and its interactions with plant communities and advocated for further study to better quantify the 
effects of different land management and crop regimes on the soil microbial community.

Our overarching objective was to quantify characteristics of soils under plant communities with invasive plant species and contrast these characteristics with those of soils under native vegetation. Specifically, we wished to determine: i) if invasive plant species alter soil physical, chemical, or biological properties; and ii) the long-term effects of invasive plant species on soil properties and subsequent implications on ecological restoration efforts. We hypothesized that soils under invasive species would differ in notable characteristics from soils under native vegetation; examples include soil bulk density, soil $\mathrm{pH}$, important macro- and micro-nutrients, presence of allelochemicals, and soil microbial community structure and function. Changes that enhance the invasive plant's competitive ability were expected. If these changes persist, then restoration of native vegetation may be more complex and require more time than previously assumed.

\section{Materials and methods}

\subsection{Study sites}

We compared two reconstructed prairies, varying slightly in age, with a native prairie remnant and an unrestored, heavily invaded old field. All study sites were located in central Missouri within a $48 \mathrm{~km}$ radius (Fig. 1) centered around Tucker Prairie Natural Area. The soils at all sites are within Major Land Resource Area 113, "Central Claypan Area," and are generally deep, well-drained to poorly drained and formed in loess and/or pedisediment over glacial till (USDA, NRCS 2006). A claypan typically occurs in the dominant soils at a depth range of 20 to $30 \mathrm{~cm}$ but may be as shallow as within 8 to $10 \mathrm{~cm}$ of the surface on eroded areas and side slopes. The claypan restricts drainage and the water table is often perched just $30 \mathrm{~cm}$ below ground on the flattest portion of the landscape.

The native prairie remnant, Tucker Prairie Natural Area $\left(38.9485^{\circ} \mathrm{N}, 91.9943^{\circ} \mathrm{W}\right)$ (Fig. 1B), consists of 59 ha of native prairie; it is perhaps the best example of the tallgrass prairie ecosystem that once covered north-east and central Missouri. Over 250 species representing 70 families and 150 genera of grasses and forbs have been identified on Tucker Prairie (TP); grasses make up a full $50 \%$ of herbaceous cover with four species: Andropogon gerardii, Schizachyrium scoparium, Sorghastrum nutans, and Sporobolus heterolepis being the ecosystem dominants (Kucera, 1956). While not completely undisturbed, (e.g., it has been grazed and mowed and is managed with periodic prescribed burns) this area has never
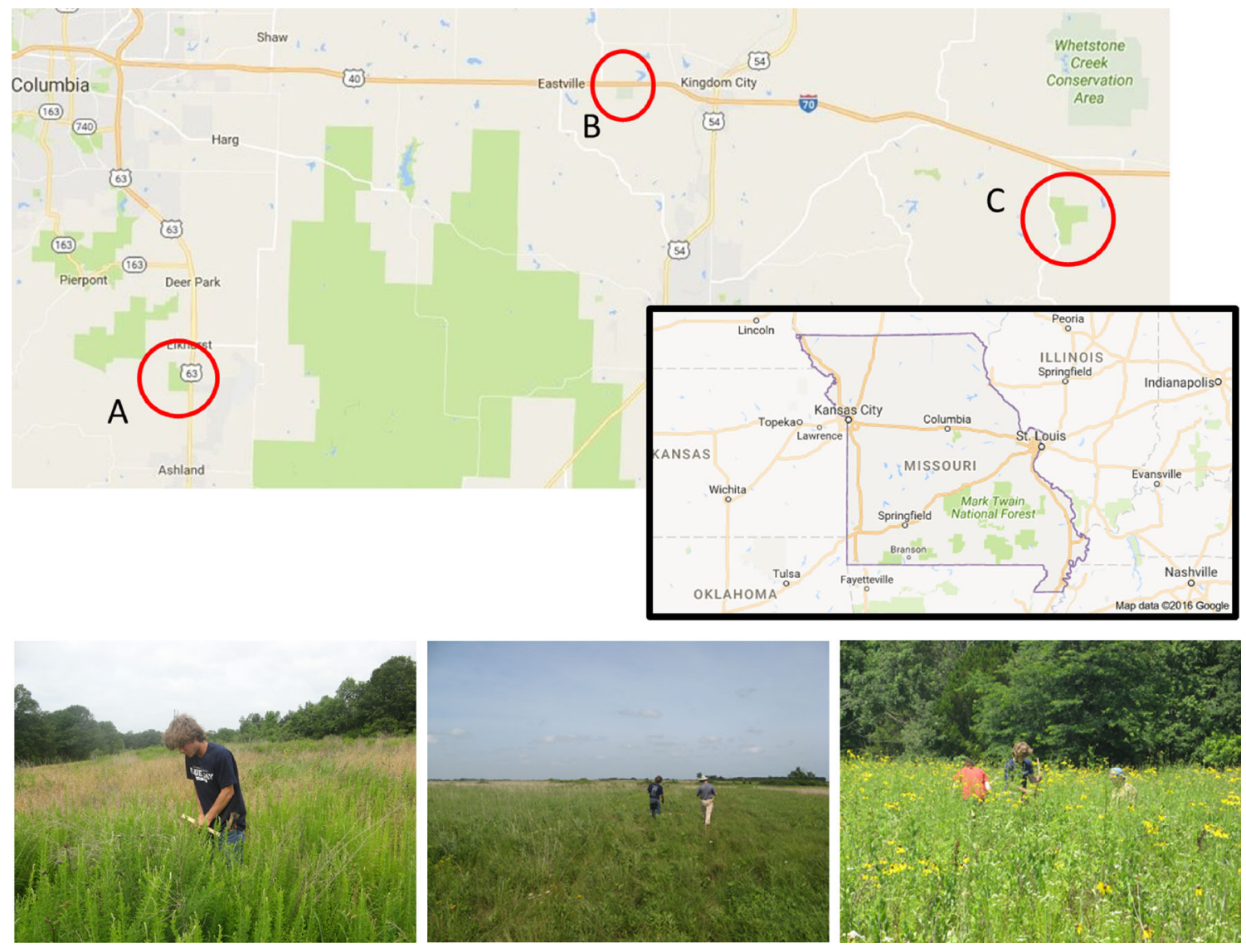

Fig. 1 Study sites: (A) Green Conservation Area (left photo); (B) Tucker Prairie Natural Area (middle photo); (C) Prairie Fork Conservation Area (right photo). 
been plowed. The soil series at TP sample sites is Mexico silt loam (fine, smectitic, mesic Aeric Vertic Epiaqualfs).

The Charles W. Green Conservation Area (38.810621 ${ }^{\circ} \mathrm{N}$, 92.258147 $\mathrm{W}$ ) (Fig. 1A) served as our unrestored/invaded site. This 138 ha area, donated to the Missouri Department of Conservation in 1956, was once a part of a large pre-civil war plantation. Prior to 1956, a variety of crops including wheat, corn, rye, and oats were cultivated at the Green Area (GA), at which a number of different livestock species were also produced. The area is no longer under cultivation; currently, it houses an office and machine shop and is utilized for a variety of special deer hunts. Little, if any, restoration has occurred on this site and as such a number of invasive species including $L$. cuneata, Schedonorus arundinaceus, Lonicera maackii, Lonicera X bella, and others appeared shortly after 1956 are currently prevalent. Soils at GA sampling sites are within the Mexico-Keswick (fine, smectitic, mesic Aquertic Chronic Hapludalfs)-Leonard (fine, smectitic, mesic Vertic Epiaqualfs) association.

The reconstructed prairies were located at Prairie Fork Conservation Area (PFCA $38.8927^{\circ} \mathrm{N}, 91.7332^{\circ} \mathrm{W}$ ) (Fig. 1C); this 288 ha site was under agricultural production prior to being donated to the Missouri Department of Conservation in 1997. Approximately 49 ha of PFCA are under active restoration which involves cropping fields with conventional tillage for three to five years under a typical corn and soybean rotation to reduce invasive species populations, including $L$. cuneata, and to create a clean seedbed for broadcast seeding with local ecotypes. Tucker Prairie (26 km to the west) served as a model for this restoration as well as a major source of seeds; other seed sources included the Marshall Diggs Conservation Area $\left(39^{\circ} 4^{\prime} 17^{\prime \prime} \mathrm{N}, 91^{\circ} 37^{\prime} 36^{\prime \prime} \mathrm{W}\right)(24 \mathrm{~km}$ to the east) as well as other sites within $48-64 \mathrm{~km}$ of PFCA. Seeds were collected from mid-May to early November rotating through sites, visiting the best sites once every two weeks. Seeds were then dried, bagged, and mixed with potash (to aid in seed spreading); these seeds were supplemented with purchases from vendors who raise local ecotype seed. Restored sites are monitored for invasive species, which are spot-treated with herbicides; periodic prescribed fire is also used to prevent intrusion of woody species (George, 2011; Newbold et al., 2020). At least 183 taxa have been documented at PFCA (Newbold et al., 2020); observations include several grasses (Schizachyrium scoparium, Tripsacum dactyloides, Bouteloua curtipendula and Sorghastrum nutans) as well as numerous perennial forbs. The two PFCA sampling sites differed in when they were seeded; one was seeded in 2011, representing four years post-restoration (PF11), and the second was seeded in 2013, representing two years post-restoration (PF13). Soils at PF11 and PF13 sampling sites are within the Mexico-Armstrong (fine smectitic, mesic Aquertic Hapludalfs) association.

\subsection{Soil collection and analysis}

At each site, we collected four composite soil samples in June
2015 at two depths $(0-5 \mathrm{~cm}$ and $5-10 \mathrm{~cm})$ at random locations within a site and avoiding the field edges. For each composite sample, 15-20 small core samples (2 cm diameter) were randomly collected within an area of $\sim 4 \mathrm{~m}^{2}$. At GA, soils were intentionally collected from within the rooting zone of $L$. cuneata, while at the other three sites, L. cuneata was intentionally avoided. In addition, one core sample $(7.5 \mathrm{~cm} \times$ $7.5 \mathrm{~cm}$; diameter $\times$ depth) was collected from near the center of each field in order to measure soil bulk density. Composite samples were stored at $4^{\circ} \mathrm{C}$ upon return to the laboratory. A small portion of each composite sample was frozen; these subsamples were later utilized for microbial analysis. The remainder of each sample was moist sieved ( $2 \mathrm{~mm}$ mesh) and then air-dried. Several physical, chemical, and biological variables were measured to characterize the soil environment.

\subsection{Soil physical and chemical properties}

Physical properties such as soil texture, bulk density, and water-stable aggregates (WSA), along with a variety of chemical variables [i.e., $\mathrm{pH}$, electrical conductivity $(\mathrm{EC})$, $\mathrm{NH}_{4} \mathrm{Cl}$ extractable bases, cation exchange capacity (CEC), total organic $C$ (TOC), active carbon, total $N(T N)$, potentially mineralizable $\mathrm{N}$ (PMN), and soil phenolic carbon] were used to give an indication of suitable habitat for soil microorganisms. Soil samples were sent to the Soil Health Assessment Center at the University of Missouri South Farm Research Center (Columbia, $\mathrm{MO}$ ) for determination of $\mathrm{NH}_{4} \mathrm{Cl}$ extractable bases (i.e., $\mathrm{Ca}^{2+}, \mathrm{Mg}^{2+}, \mathrm{Na}^{+}, \mathrm{K}^{+}$), $\mathrm{CEC}, \mathrm{PMN}$ (incubation method) and aggregate stability (i.e., 1-2 $\mathrm{mm}$ water-stable aggregates as determined by the sieve dipping method). Samples were also processed at the USDA-ARS Cropping Systems and Water Quality Research Unit housed on the campus of the University of Missouri. This laboratory assessed samples for $\mathrm{pH}, \mathrm{EC}, \mathrm{TOC}, \mathrm{TN}$, active carbon $\left(\mathrm{KMnO}_{4}\right.$ oxidation technique) and water-soluble phenolic carbon (following Ohno et al., 2002). Total organic C and TN contents of each composite sample were determined by dry combustion at $900^{\circ} \mathrm{C}$ (Nelson and Sommers, 1996) using a LECO TruSpec C/N analyzer (LECO Corp., St. Joseph, MI).

\subsection{Soil biological properties}

Determination of soil microbial community function was limited to $\mathrm{N}$ - and $\mathrm{C}$-utilization patterns; $\beta$-glucosaminidase and $\beta$ glucosidase (respectively) were employed. Methods followed those outlined in Deng and Popova (2011) and were conducted at the USDA-ARS laboratory. For both assays, spectrophotometer readings from incubated soil samples were compared with a standard curve, using $p$-nitrophenol (PNP) as the standard. Activities are reported as $\mu \mathrm{g} p$ nitrophenol released per gram soil per hour (i.e., $\mu \mathrm{g}$ PNP released $\mathrm{g}^{-1}$ soil $\mathrm{h}^{-1}$ ).

Soil microbial community biomass and structure were assessed through phospholipid fatty acid analysis (PFLA) 
on previously frozen soil samples. This analysis was conducted at the Soil Health Assessment Center using the high throughput extraction methodology outlined by Buyer and Sasser (2012). Peaks were identified using Sherlock Software version 6.0 (MIDI Corp, Newark, NJ). This software assigns each PLFA peak to one of the fatty acid type categories and then sums fatty acids into biomarker groups: arbuscular mycorrhizae fungi, actinomyces (actinobacteria), Gram-negative bacteria, Gram-positive bacteria, anaerobic bacteria, and eukaryotes (for peak assignments, see Buyer and Sasser, 2012).

\subsection{Statistical analysis}

Analysis of Variance (ANOVA) (NCSS 9.1) followed by Tukey Tests were utilized to assess the observed differences between treatments at $\alpha=0.05$. Each field sampled was several hectares in size; therefore, the four composite samples collected within a field were treated as replicates. Each soil property was compared separately as were the two sampling depths.

\section{Results}

Where significant differences were observed, the unplowed prairie reference site (i.e., Tucker Prairie) differed from the other three sites. Further analyses revealed that the restored sites (i.e., PF11 and PF13) generally did not differ from the invaded old-field site (i.e., Green Area).

\subsection{Soil physical and chemical properties}

Soil color and texture were generally consistent across the four sites; common colors were 10YR 4/2, 10YR 3/2, and 10YR $3 / 1$, while textures were predominantly clay loam. Soils at TP had significantly reduced bulk density $(p<0.0001)$ (Table 1$)$ and greater water stable aggregates $(p=0.001)$ (Table 2) than soils at all other sites. Few differences were identified through examination of $\mathrm{NH}_{4} \mathrm{Cl}$ extractable bases (Table 2). Soils at TP had twice the extractable $\mathrm{Na}^{+}(p=0.002)$ than all other sites and significantly lower $\mathrm{pH}(p=0.0002)$ than the restored sites. Soils did not vary in EC or CEC (Table 2). Tucker Prairie had greater $\mathrm{C}$ and $\mathrm{N}$ resources than the other three sites (Figs. 2-3). Surface soils (0-5 cm depth) at TP had $15 \%$ greater active C (Fig. 3), 40\%-45\% greater TOC (Fig. 2), and $35 \%-38 \%$ greater TN (Fig. 2) than soils at the GA and the PF sites. Similar trends were observed for the subsurface soils (5-10 cm depth). Potentially mineralizable N was $20 \%-$ $25 \%$ greater (Fig. 3); however, these differences were not significant $(0-5 \mathrm{~cm}, p=0.24 ; 5-10 \mathrm{~cm}, p=0.08)$. Water soluble phenolic carbon did not differ between the sites (data not shown; $p=0.16$ ). In general, the reconstructed prairies (PF11 and PF13) did not differ from the invaded site (GA) for these measures (Figs. 2-3).

\subsection{Soil biological properties}

Assessment of soil microbial community function revealed few differences (Fig. 4). No clear trends were discernable, and no significant differences observed $(0-5 \mathrm{~cm}, p=0.74 ; 5-10 \mathrm{~cm}, p$ $=0.64)$ for C-utilization as determined by $\beta$-glucosidase activity. However, $\mathrm{N}$-utilization in surface soils $(0-5 \mathrm{~cm})$, as determined by $\beta$-glucosaminidase, was $28 \%$ greater at TP than at the other three sites; this difference was not significant $(p=0.06)$. The invaded and rehabilitated sites had the same $\mathrm{N}$ cycling capacity at both sampling depths (Fig. 4).

Tucker Prairie soils had a much more robust soil microbial community than soils of the reconstructed prairies or the invaded site (Fig. 5A). Analyses revealed 33\% more mycorrhizae (Fig. 5B) $(p=0.002), 46 \%$ more actinobacteria (Fig. 5C) ( $p<0.0001)$, 49\% more Gram-negative bacteria (Fig. 5D) $(p<0.0001)$, and 50\% more Gram-positive bacteria (Fig. 5E) $(p<0.0001)$ in the soils at TP compared to the other three sites. Tucker Prairie also supported $40 \%$ greater fungi and $24 \%$ greater anaerobic bacteria than the other three sites (data not shown), although these differences were not significant (fungi, $p=0.06$; anaerobic bacteria, $p=0.09$ ). Overall, TP had $45 \%$ more microbial biomass than the GA or the PF sites ( $p=0.0002)$. Overall, the microbial community structure of the reconstructed prairies was not different from the invaded site (Fig. 5).

\section{Discussion}

\subsection{Soil physical and chemical properties}

Soils at the native prairie site (TP) differed from those of the reconstructed prairies (PF11 and PF13) as well as from those at the unrestored/invaded site (GA) for most soil characteristics that were studied. Tucker Prairie had lower bulk density and greater water stable aggregates, greater soil $\mathrm{C}$ and $\mathrm{N}$ resources and a more robust microbial community than the other sites. These factors are interrelated and can be attributed, at least partially, to TP's management history. The significantly lower soil $\mathrm{pH}$ at TP is an inherent characteristic of hardpan prairie terrestrial natural communities where soils that are poorly drained develop very strongly acid to moderately acid soil reaction due to the presence of a claypan that impedes water infiltration and runoff (Nelson, 2005). Because soil $\mathrm{pH}$ was higher at the rehabilitated sites, the change in soil reaction was most likely due to previous agricultural management imposed at these sites rather than to the long-term growth of $L$. cuneata. Overall, it is common for soil $\mathrm{pH}$ to be higher in agricultural land compared with adjacent prairie soils due to differences in organic matter content and root exudates (Brye and Pirani, 2005).

Tucker Prairie has never been plowed; the lack of this disturbance explains why this site had soils that were less dense and contained a greater percentage of WSA. Water 

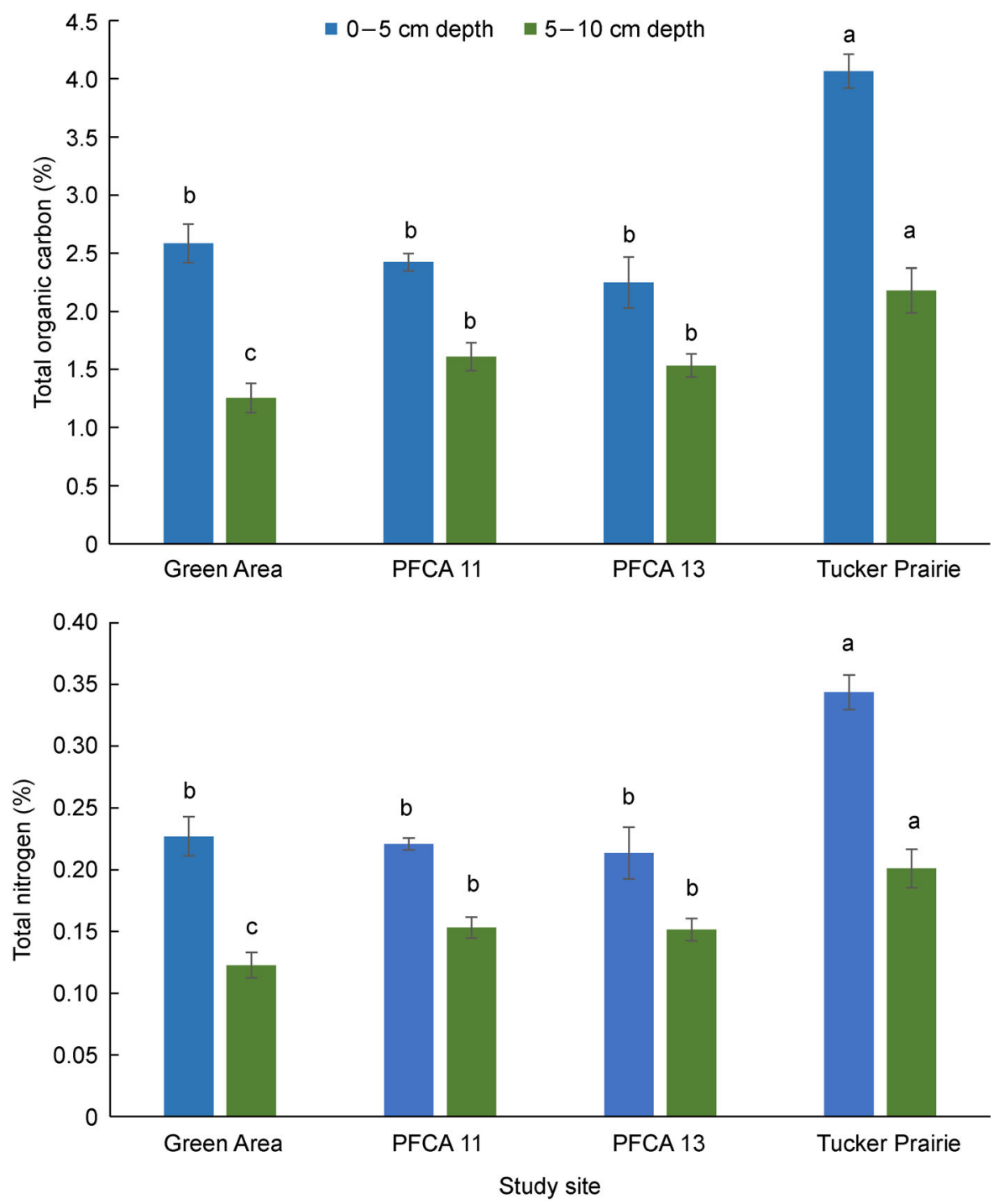

Fig. 2 Total soil carbon (top) and nitrogen (bottom) resources for soils i) invaded with Lespedeza cuneata (Green Area), ii) restored to prairie for 4 years (PFCA 11), iii) restored to prairie for 2 years (PFCA 13), and iv) from a native prairie (Tucker Prairie). Surface soils ( $0-5 \mathrm{~cm}$ sampling depth) were analyzed separately from sub-surface soils $(5-10 \mathrm{~cm}$ sampling depth); for same sampling depth different letters indicate significant differences $(\alpha=0.05)$. Error bars represent \pm one standard deviation.

stable aggregates help determine soil porosity and, in turn, water, nutrient, and root movement through the soil profile. Larger aggregates are more sensitive to management effects on soil organic matter (SOM) and, thus, they are associated with higher soil quality. For example, in their study of Piedmont soils in Georgia, Beare et al. (1994) observed greater percentages of macroaggregates under no-tillage systems than under conventional-tillage; conversely, small WSA size classes were more prevalent under conventional-tillage. They also observed greater total as well as mineral-associated $\mathrm{C}$ and $\mathrm{N}$ stocks under no-tillage systems (Beare et al., 1994). Bulk density is an indicator of soil compaction; it is dependent on SOM and soil texture but can also be affected by management techniques such as plowing and animal and equipment traffic. All four sites had similar soil texture (i.e., clay loam) and similar extractable base cation contents; therefore, we can rule out soil texture as a contributing factor to the observed differences in bulk density and WSA. Similarly, all four sites were under similar vegetation (i.e., grasses and forbs); therefore, we might assume similar residues and contributions to SOM. For the sites evaluated in this study, soil nutrient contents did not differ among the invaded site (GA) and non-invaded sites (PF), suggesting a greater influence of agricultural management on these abiotic factors than of $L$. cuneata. Previous reports of invasive plant effects on soil nutrient contents are similarly conflicting whereby significant shifts were caused by three invasive species (Gibbons et al., 2017) while no effects were observed for other invasive plants (Tekiela and Barney, 2017). Waller et al. (2020) demonstrated that exotic species, with their novel biochemical inputs, may affect C-cycling by enhancing the rate of microbial mineralization of organic matter. Our study 

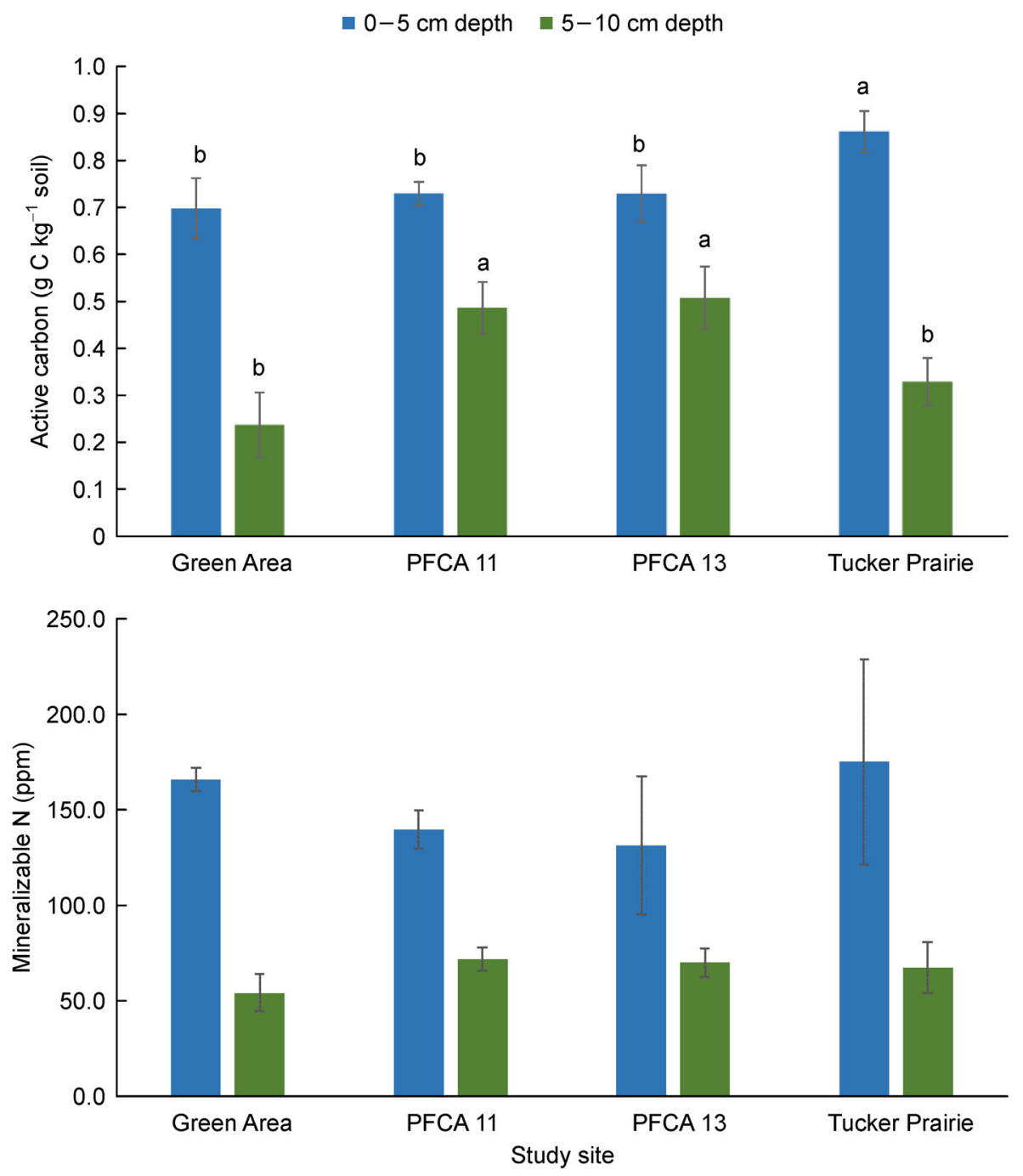

Fig. 3 Readily available carbon (top) and nitrogen (bottom) resources for soils i) invaded with Lespedeza cuneata (Green Area), ii) restored to prairie for 4 years (PFCA 11), iii) restored to prairie for 2 years (PFCA 13), and iv) from a native prairie (Tucker Prairie). Surface soils ( $0-5 \mathrm{~cm}$ sampling depth) were analyzed separately from sub-surface soils (5-10 cm sampling depth); for same sampling depth different letters indicate significant differences $(\alpha=0.05)$. Error bars represent \pm one standard deviation.

was conducted on claypan soils, which offers a considerably unique environment compared with other studies and was likely a major factor influencing plant growth and effects on soil properties.

\subsection{Soil biological properties}

When considering the soil microbial community, the management differences between our sites become even more relevant. All sites, except TP, were under agricultural management (i.e., previously plowed) at some point in their history. Although, it should be noted that the GA has not been plowed for at least 60 years. The mixing effect of plowing results in enhanced nutrient cycling and subsequent reductions in SOM as well as negative impacts on soil organisms
(Beare et al., 1994; Thiele-Bruhn et al., 2012; Rosenzweig et al., 2016). For example, in their examination of a

Table 1 Bulk density for soils i) invaded with Lespedeza cuneata (Green Area), ii) restored to prairie for 4 years (PFCA 11), iii) restored to prairie for 2 years (PFCA 13), and iv) from a native prairie (Tucker Prairie).

\begin{tabular}{ll}
\hline Study site & Bulk density $\left(\mathrm{g} \mathrm{cm}^{-3}\right)$ \\
\hline Green Area & $1.05 \mathrm{a}$ \\
PFCA 11 & $1.19 \mathrm{a}$ \\
PFCA 13 & $1.21 \mathrm{a}$ \\
Tucker Prairie & $0.77 \mathrm{~b}$ \\
\hline
\end{tabular}

Means followed by different letters are significantly different $(\alpha=0.05)$. 
Table 2 Select physical and chemical properties for soils i) invaded with Lespedeza cuneata (Green Area), ii) restored to prairie for 4 years (PFCA 11), iii) restored to prairie for 2 years (PFCA 13), and iv) from a native prairie (Tucker Prairie).

\begin{tabular}{|c|c|c|c|c|c|c|c|c|c|}
\hline & \multirow[t]{3}{*}{ WSA (\%) } & \multirow[t]{3}{*}{$\mathrm{pH}$} & \multirow[t]{3}{*}{ EC } & \multirow{2}{*}{\multicolumn{5}{|c|}{$\begin{array}{c}\mathrm{NH}_{4} \mathrm{Cl} \text { extractable bases } \\
\mathrm{mEq} \text { per } 100 \mathrm{~g}\end{array}$}} & \multirow[t]{3}{*}{ CEC } \\
\hline & & & & & & & & & \\
\hline & & & & $\mathrm{Ca}$ & $\mathrm{Mg}$ & $\mathrm{Na}$ & $\mathrm{K}$ & Sum & \\
\hline \multicolumn{10}{|l|}{$0-5 \mathrm{~cm}$} \\
\hline Green Area & $43.8 \mathrm{~b}$ & $5.0 \mathrm{~b}$ & $52.8 \mathrm{a}$ & $12.3 \mathrm{a}$ & $2.5 \mathrm{a}$ & $0.1 \mathrm{~b}$ & $0.3 \mathrm{a}$ & $15.2 \mathrm{a}$ & $16.3 \mathrm{a}$ \\
\hline PFCA 11 & $40.2 \mathrm{~b}$ & $5.6 \mathrm{a}$ & $50.3 \mathrm{a}$ & $16.1 \mathrm{a}$ & $3.1 \mathrm{a}$ & $0.1 \mathrm{~b}$ & $0.4 \mathrm{a}$ & $19.7 \mathrm{a}$ & $18.4 \mathrm{a}$ \\
\hline PFCA 13 & $33.1 \mathrm{~b}$ & $5.5 \mathrm{a}$ & $38.9 \mathrm{a}$ & $15.0 \mathrm{a}$ & $3.0 \mathrm{a}$ & $0.1 \mathrm{~b}$ & $0.3 a$ & $18.4 \mathrm{a}$ & $17.1 \mathrm{a}$ \\
\hline Tucker Prairie & $69.6 \mathrm{a}$ & $4.8 \mathrm{~b}$ & $39.9 \mathrm{a}$ & $12.2 \mathrm{a}$ & $2.9 \mathrm{a}$ & $0.2 \mathrm{a}$ & $0.4 \mathrm{a}$ & $15.7 \mathrm{a}$ & $18.9 \mathrm{a}$ \\
\hline \multicolumn{10}{|l|}{$5-10 \mathrm{~cm}$} \\
\hline Green Area & $7.8 \mathrm{a}$ & $5.0 \mathrm{~b}$ & $40.9 \mathrm{a}$ & $10.2 a b$ & $2.1 \mathrm{a}$ & $0.05 b$ & $0.2 \mathrm{a}$ & $12.5 a b$ & $14.0 \mathrm{a}$ \\
\hline PFCA 11 & $17.1 \mathrm{a}$ & $5.7 \mathrm{a}$ & $39.0 \mathrm{a}$ & $15.0 \mathrm{a}$ & $2.8 \mathrm{a}$ & $0.10 \mathrm{~b}$ & $0.2 \mathrm{a}$ & $18.1 \mathrm{a}$ & $17.5 \mathrm{a}$ \\
\hline PFCA 13 & $11.2 \mathrm{a}$ & $5.8 \mathrm{a}$ & $39.2 \mathrm{a}$ & $14.3 \mathrm{a}$ & $2.8 \mathrm{a}$ & $0.10 \mathrm{~b}$ & $0.2 \mathrm{a}$ & $17.4 \mathrm{a}$ & $16.1 \mathrm{a}$ \\
\hline Tucker Prairie & $17.7 \mathrm{a}$ & $4.9 \mathrm{~b}$ & $25.1 \mathrm{a}$ & $7.5 \mathrm{~b}$ & $2.2 \mathrm{a}$ & $0.20 \mathrm{a}$ & $0.2 \mathrm{a}$ & $10.1 \mathrm{~b}$ & $14.2 \mathrm{a}$ \\
\hline
\end{tabular}

Surface soils ( $0-5 \mathrm{~cm}$ sampling depth) were analyzed separately from sub-surface soils $(5-10 \mathrm{~cm}$ sampling depth); means followed by different letters are significantly different $(\alpha=0.05)$.

chronosequence of prairie restoration sites, Rosenzweig et al. (2016) observed total $\mathrm{C}$ and $\mathrm{N}$ pools were half as great in cultivated soils as in native soils. Moreover, Rosenzweig et al. (2016) suggest that total $C$ and $N$ pools may develop slowly and estimate that over 300 years may be required to return $C$ and $\mathrm{N}$ pools of previously cultivated soils to levels observed in native prairies. Tucker Prairie soils had greater $\mathrm{C}$ and $\mathrm{N}$ resources as well as a more robust microbial community than the reconstructed prairies or the unrestored/invaded old field. Differences in soil TOC and TN between Tucker Prairie and our other sites were in the range observed by Rosenzweig et al. (2016); utilization of different methods of quantifying microbial biomass do not allow direct comparisons between studies for this variable. However, the observation of much greater microbial biomass on native sites as opposed to restored sites is evident in both studies. Of note is the greater prevalence of AMF and total fungi at TP; plowing has been demonstrated to disrupt fungal hyphal networks and overall reduce the abundance of fungal species (Thiele-Bruhn et al., 2012). The higher SOC, TN, and AC contents along with the lower $\mathrm{pH}$ likely contributed to the higher microbial biomass (total PLFA content) and greater abundance of microbial components at the TP site. The significantly lower microbial parameters noted for the other sites were likely a result of the previous agricultural management coupled with early invasive plant-mediated shifts with subsequent contributions to the current longer-term shifts in soil biological properties, as noted for other invasive plants (Gibbons et al., 2017). For example, Murugan et al. (2020), in their study of invasive species removal in Southern India, reported invasive leguminous species decreasing SOC and microbial biomass C.

\subsection{Lag effects in restoration}

As previously noted, numerous studies have shown that the soil microbial community responds to changes in vegetation. While it might be valid to assume that the soil microbial community responds quickly to these changes, some studies (Buckley and Schmidt, 2003; Mckinley et al., 2005; Card and Quideau, 2010; Jangid et al., 2010; Fichtner et al., 2014) suggest that there is a lag time between vegetation community restoration and recovery of soil characteristics, including the soil microbial community. Three of these investigations (Buckley and Schmidt, 2003; Mckinley et al., 2005; Jangid et al., 2010) had a design similar to ours: a highly disturbed or agricultural site, restored sites of different ages, and a native prairie remnant.

Buckley and Schmidt (2003) made their comparisons among Long-term Ecological Research (LTER) sites at the Kellogg Biological Station in $\mathrm{Ml}$; their intermediate sites were the product of successional processes as opposed to active restoration and were approximately 10 and 50 years old. Microbial community structure in their early successional site did not differ from that of the conventionally tilled site, while the long-term successional site and the native prairie site were not different. However, the conventionally tilled site differed significantly from the late successional site and the native prairie site. Their results suggest soil properties can return to pre-agricultural conditions as succession progresses; however, these changes may take decades (i.e., more than 10 years and at least 45 years) (Buckley and Schmidt, 2003). They conclude that site history is important; agriculture depletes soil $\mathrm{C}$ and $\mathrm{N}$ pools, and these pools require 

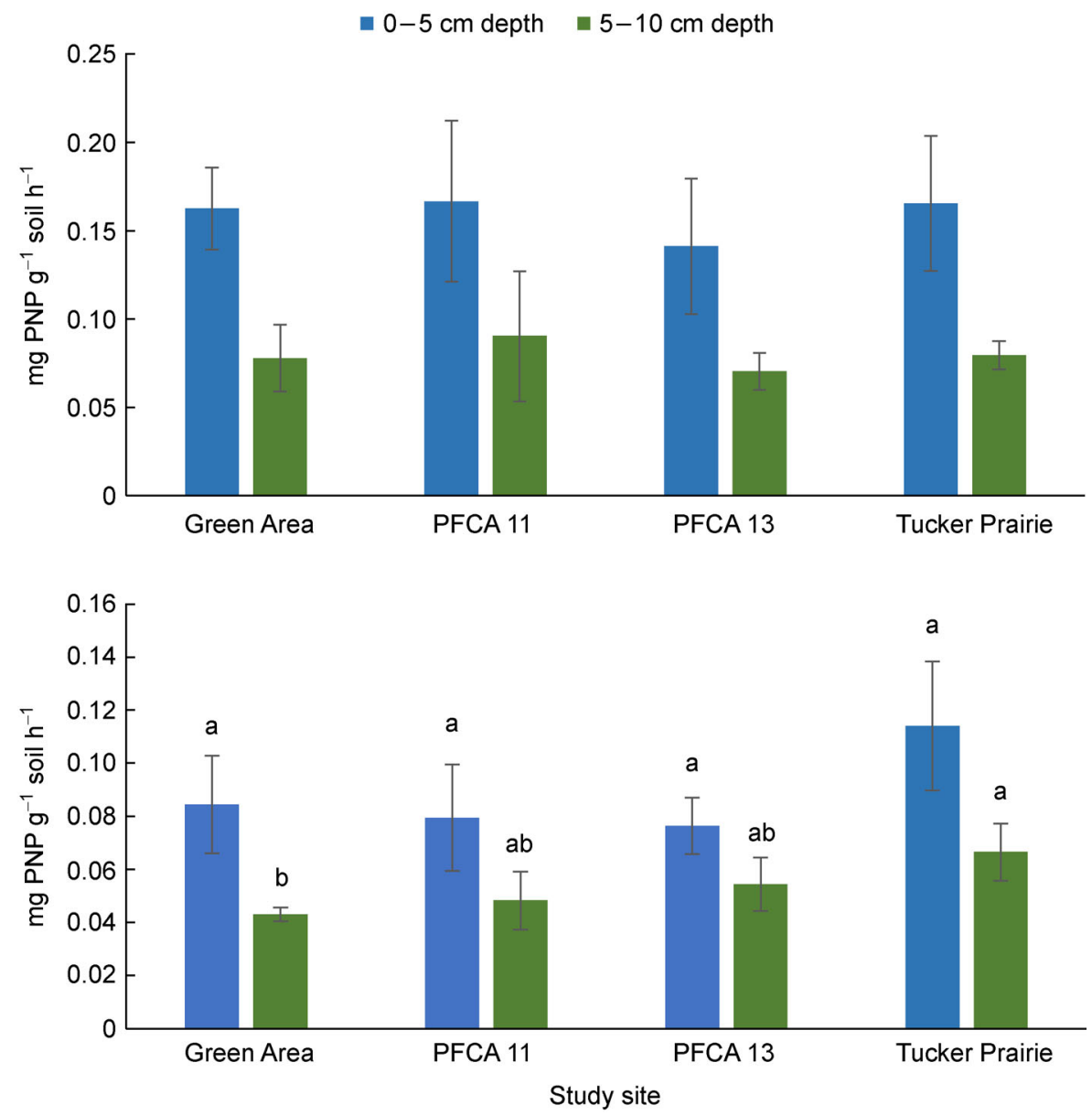

Fig. 4 Soil microbial community function as determined by $\beta$-glucosidase (i.e., carbon activity, top) and $\beta$-glucosaminidase (i.e., nitrogen activity, bottom) for soils i) invaded with Lespedeza cuneata (Green Area), ii) restored to prairie for 4 years (PFCA 11), iii) restored to prairie for 2 years (PFCA 13), and iv) from a native prairie (Tucker Prairie). Surface soils ( $0-5 \mathrm{~cm}$ sampling depth) were analyzed separately from sub-surface soils (5-10 cm sampling depth); for same sampling depth different letters indicate significant differences $(\alpha=0.05)$. Error bars represent \pm one standard deviation.

significant time to recover. Consequently, slow recovery of soil nutrients may translate into slow recovery of microbes (Buckley and Schmidt, 2003).

Similarly, Jangid et al. (2010) made use of LTER sites (Konza Prairie, KS); reconstructed prairies at this location were approximately 8 - and 28 -year old. This time sequence provided evidence for reestablishment of native conditions over time; physiochemical characteristics approached those of the native prairie while total microbial biomass increased consistently with age of restoration. However, bacteria and fungi increased at different rates with some groups only present during the restoration process. The authors suggest that these transitional microbial communities may respond to temporary physiochemical conditions present during restoration, highlighting the complex nature of the soil microbial community response. Jangid et al. (2010) concluded that, as a whole, soil microbes may respond slowly. Even after 28 years, the soil microbial community still differed from that of the native prairie, and they suggested that the cessation of disturbance may be more important than changes in the species composition of the above-ground plant community.

Finally, Mckinley et al. (2005) investigated a system similar to Jangid et al. (2010) in terms of ages of restored prairie systems; their recently restored site was 7 years old and the long-term restored prairie was 24 years old. In terms of soil chemistry, their restored sites were, in general, intermediate between their agricultural and virgin prairie sites (Mckinley et al., 2005). Similar to Jangid et al. (2010), total microbial biomass was greater in the long term restored prairie and in the virgin prairie than in the recently-restored prairie or agricultural site but again, individual group response was more complicated (Mckinely et al., 2005). Mckinely et al. (2005) concluded that while their restored sites were progressing toward the characteristics of the native prairie, additional time was needed for full restoration. They noted estimates of 45 years or longer for SOM in the top $5 \mathrm{~cm}$ of soil of restored prairies to reach levels of a virgin prairie. Soil microbes are assumed to respond to these changes in SOM, but it is not known if they require 45 years or if they can recover more quickly (Mckinley et al., 2005). 

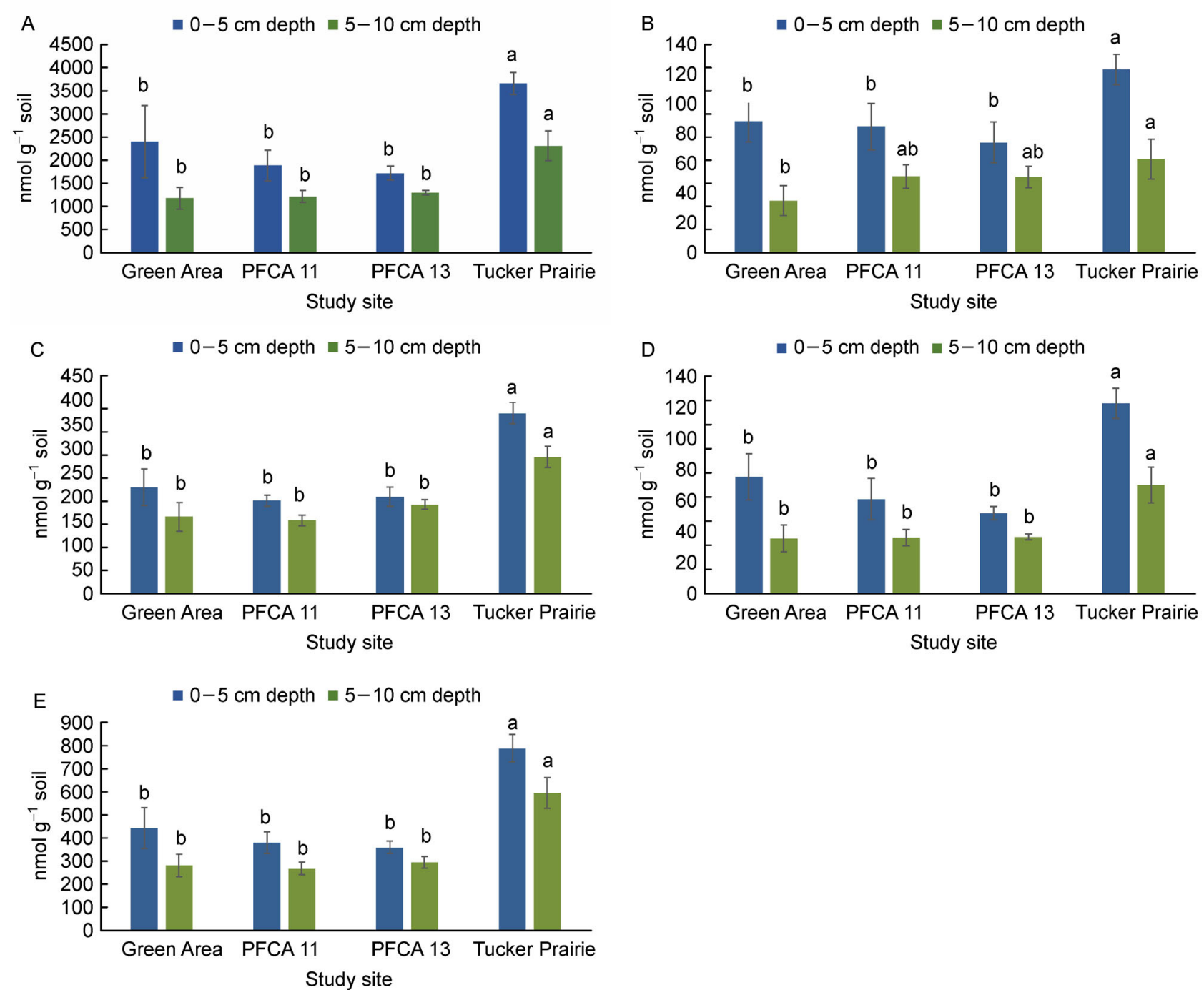

Fig. 5 Estimate of microbial biomass by microbial group for soils i) invaded with Lespedeza cuneata (GA), ii) restored to prairie for 4 years (PF11), iii) restored to prairie for 2 years (PF13), and iv) from a native prairie (TP). Total microbial biomass (A), along with arbuscular mycorrhizae fungi (B), actinobacteria (formerly actinomycetes) (C), Gram-negative bacteria (D), and Grampositive bacteria $(E)$ are presented. Surface soils ( $0-5 \mathrm{~cm}$ sampling depth) were analyzed separately from sub-surface soils (5$10 \mathrm{~cm}$ sampling depth); for same sampling depth different letters indicate significant difference $(\alpha=0.05)$. Error bars represent \pm one standard deviation.

These studies provide evidence for a slow recovery of the soil microbial community during restoration. The aboveground community may resemble a prairie, but the belowground one may not. Other systems may recover more or less quickly. Card and Quideau (2010) suggested that restored wetlands in the Canadian prairie pothole region approached the characteristics of the reference sites in 7-10 years. On the other hand, Fichtner et al. (2014) proposed that a century might be required for soil microbial communities of oak forests to recover fully. It is important to note, that every case mentioned here is on a different time scale than the current study. Our sites were planted to prairie in 2011 and 2013 and as such, they were only 2 and 4 years old when sampled. The soil microbial communities of the PFCA sites were in the early stages of recovering from past agricultural management at the time of this study.

Moreover, Elgersma et al. (2011) determined through their work with invasive plants (e.g., Berberis thunbergii) on plantsoil interactions that previous vegetation was more important in determining soil microbial community structure and function than current vegetation. Their work suggests that killing or removing above ground vegetation without the removal of roots or rhizomes of invasive plants may thwart ecological restoration efforts by continued influence on the soil microbial community (Elgersma et al., 2011). These legacy effects may be particularly important if the invasive species under 
consideration is allelopathic. Plants with allelopathic capabilities may displace native vegetation in the short term but have a much longer impact on the soil microbial community (Grove et al., 2012). Given that $L$. cuneata is a suspected allelopathic plant, time to full restoration may be longer than the $30-45$ years suggested by others (Buckley and Schmidt, 2003; Mckinely et al., 2005; Jangid et al., 2010). Recovery of soil characteristics similar to that of native prairies certainly requires more than the $2-4$ years that have passed since the PF sites were replanted. These sites should be resampled periodically (e.g., every 5-10 years) to determine more conclusively the recovery timeline for soil characteristics in this system.

\section{Conclusions}

Successful aboveground restoration does not necessarily mean successful belowground restoration. Given the important role of the soil microbial community in nutrient cycling, soil health indicators must be considered in the determination of the success of any terrestrial plant community restoration effort. Recent advances in metagenomics that provide full characterization of the soil and rhizosphere microbiomes can greatly increase our understanding how invasive plants affect below-ground biology and ecology. Application of such microbiome-based investigations will support development of management practices aimed at prairie ecosystem reconstruction at sites that are heavily invaded (Coats and Rumpho, 2014). Further research is necessary to determine how nutrient cycling and other ecosystem services provided by the soil microbial community might be affected by changes in the aboveground communities over time. Moreover, this study demonstrates the importance of Long-term Ecological Research (LTER) sites and of long-term monitoring of restored ecosystems.

\section{Acknowledgments}

This work was supported by a research grant from the Prairie Fork Charitable Endowment Trust. We thank USDA-ARS Cropping Systems and Water Quality Research Unit for permission to use their laboratory facilities as well as staff at the Soil Health Assessment Center for their assistance in sample analyses. The authors also wish to recognize the contribution of several undergraduate students to sample collection and analysis. We thank the University of Missouri and the Missouri Department of Conservation for access sampling sites. Any opinions, conclusions or recommendations expressed here are those of the author(s) and do not reflect the view of the USDA-ARS.

\section{Authors' contributions}

All authors were involved in the conception and development of this project; IU, KG and KV carried out field work; IU and KV carried out the laboratory work and data analysis; IU and RK led the writing of the manuscript. All authors contributed critically to the drafts and gave final approval for publication.

\section{Conflict of interest}

The authors declared that no conflicts of interest exist.

\section{References}

Beare, M.H., Hendrix, P.F., Coleman, D.C., 1994. Water-stable aggregates and organic matter fractions in conventional and notillage soils. Soil Science Society of America Journal 58, 777-786.

Brye, K.R., Pirani, A.L., 2005. Native soil quality and the effects of tillage in the Grand Prairie region of eastern Arkansas. American Midland Naturalist 154, 28-41.

Buckley, D.H., Schmidt, T.M., 2003. Diversity and dynamics of microbial communities in soils from agro-ecosystems. Environmental Microbiology 5, 441-452.

Buyer, J.S., Roberts, D.P., Russek-Cohen, E., 2002. Soil and plant effects on microbial community structure. Canadian Journal of Microbiology 48, 955-964.

Buyer, J.S., Sasser, M., 2012. High throughput phospholipid fatty acid analysis of soils. Applied Soil Ecology 61, 127-130.

Card, S.M., Quideau, S.A., 2010. Microbial community structure in restored riparian soils of the Canadian prairie pothole region. Soil Biology \& Biochemistry 42, 1463-1471.

Chacón, N., Herrera, I., Flores, S., González, J.A., Nassar, J.M., 2009. Chemical, physical, and biochemical soil properties and plant roots as affected by native and exotic plants in Neotropial arid zones. Biology and Fertility of Soils 45, 321-328.

Coats, V.C., Rumpho, M.E., 2014. The rhizosphere microbiota of plant invaders: an overview of recent advances in the microbiomics of invasive plants. Frontiers in Microbiology 5, 368.

Cummings, D.C. Bidwell, T.G., Medlin, C.R., Fuhlendorf, S.D., Elmore, R.D., Weir, J.W., 2017. Ecology and management of sericea lespedeza. Oklahoma Cooperative Extension Service Fact Sheet NREM-2874.

Deng, S., Popova, I., 2011. Carbohydrate Hydrolases. In: Dick, R.P., ed. Methods of Soil Enzymology, SSSA Book Ser. SSSA, Madison, WI. 185-209.

Dornbush, M.E., 2007. Grasses, litter and their interaction affect microbial biomass and soil enzyme activity. Soil Biology \& Biochemistry 39, 2241-2249.

Dudley, D.M., Fick, W.H., 2003. Effects of sericea lespedeza residues on selected tallgrass prairie grasses. Transactions of the Kansas Academy of Science 106, 166-170.

Eddy, J.A., Davidson, J., Obermeyer, B., 2003. Invasion dynamics and biological control prospects for sericea lespedeza in Kansas. Great Plains Research 13, 217-230.

Ehrenfeld, J.G., 2003. Effects of exotic plant invasions on soil nutrient cycling processes. Ecosystems (New York, N.Y.) 6, 503-523.

Elgersma, K.J., Ehrenfeld, J.G., Yu, S., Vor, T., 2011. Legacy effects overwhelm the short-term effects of exotic plant invasion and restoration on soil microbial community structure, enzyme activities, and nitrogen cycling. Oecologia 167, 733-745. 
Fichtner, A., von Oheimb, G., Hardtle, W., Wilken, C., Gutknecht, J.L. M., 2014. Effects of anthropocentric disturbances on soil microbial communities in oak forests persist for more than 100 years. Soil Biology \& Biochemistry 70, 79-87.

George, J., 2011. Remnants to restoration. Missouri Prairie Journal $32,16-19$.

Gibbons, S.M., Lekgerg, Y., Mummey, D.L., Sangwan, N., Ramsey, P. W., Gilbert, J.A., 2017. Invasive plants rapidly reshape soil properties in a grassland ecosystem. mSystems 2 e00178-16.

Grove, S., Haubensak, K.A., Parker, I.M., 2012. Direct and indirect effects of allelopathy in the soil legacy of an exotic plant invasion. Plant Ecology 213, 1869-1882.

Helm, C.A., Etheridge, V.C., 1933. Lespedeza sericea: the newest legume for Missouri. University of Missouri, College of Agriculture, Agricultural Field Station Bulletin, 331.

Ibekwe, A.M., Kennedy, A.C., Frohne, P.S., Papiernik, S.K., Yang, C. H., Crowley, D.E., 2002. Microbial diversity along a transect of agronomic zones. FEMS Microbiology Ecology 39, 183-191.

Inderjit. 2005. Soil microorganisms: An important determinant of allelopathic activity. Plant and Soil 274, 227-236.

Inderjit, van der Putten, W.H., 2010. Impacts of soil microbial communities on exotic plant invasions. Trends in Ecology \& Evolution 25, 512-519.

Jangid, K., Williams, M.A., Franzluebbers, A.J., Blair, J.M., Coleman, D.C., Whitman, W.B., 2010. Development of soil microbial communities during tallgrass prairie restoration. Soil Biology \& Biochemistry 42, 302-312.

Kalburtji, K.L., Mosjidis, J.A., 1993. Effects of sericea lespedeza root exudates on some perennial grasses. Journal of Range Management 46, 312-315.

Kao-Kniffin, J., Balser, T.C., 2008. Soil fertility and the impact of exotic invasion on microbial communities in Hawaiian forests. Microbial Ecology 56, 55-63.

Kennedy, A.C., 1999. Bacterial diversity in agroecosystems. Agriculture, Ecosystems \& Environment 74, 65-76.

Kourtev, P.S., Ehrenfeld, J.G., Ha"ggblom, M., 2003. Experimental analysis of the effect of exotic and native plant species on the structure and function of soil microbial communities. Soil Biology \& Biochemistry 35, 895-905.

Kourtev, P.S., Ehrenfeld, J.G., Huang, W.Z., 2002. Enzyme activities during litter decomposition of two exotic and two native plant species in hardwood forests of New Jersey. Soil Biology \& Biochemistry 34, 1207-1218.

Koutika, L.S., Vanderhoeven, S., Chapuis-Lardy, L., Dassonville, N., Meerts, P., 2007. Assessment of changes in soil organic matter after invasion by exotic plant species. Biology and Fertility of Soils 44, 331-341.

Kucera, C.L., 1956. Grazing effects on composition of Virgin Prairie in North-Central Missouri. Ecology 37, 389-391.

Langdale, G.W., Giddens, J.E., 1967. Phytotoxic phenolic compounds in sericea lespedeza residues. Agronomy Journal 59, 581-584.

Lankau, R., 2010. Soil microbial communities alter allelopathic competition between Alliaria petiolata and a native species. Biological Invasions 12, 2059-2068.

Macdonald, C.A., Thomas, N., Robinson, L., Tate, K.R., Ross, D.J., Dando, J., Singh, B.K., 2009. Physiological, biochemical and molecular responses of the soil microbial community after afforestation of pastures with Pinus radiata. Soil Biology \& Biochemistry 41, 1642-1651.

Mackelprang, R., Grube, A.M., Lamendella, R., Jesus, E.D.C., Copeland, A., Liang, C., Jackson, R.D., Rice, C.W., Kapucija, S., Parsa, B., Tringe, S.G., Tiedje, J.M., Jansson, J.K., 2018. Microbial community structure and functional potential in cultivated and native tallgrass prairie soils of the Midwestern United States. Frontiers in Microbiology 9, 1775.

Mckinley, V.L., Peacok, A.D., White, D.C., 2005. Microbial community PLFA and PHB responses to ecosystem restoration in tallgrass prairie soils. Soil Biology \& Biochemistry 37, 1946-1958.

Mungai, N.W., Motavalli, P.P., Kremer, R.J., Nelson, K.A., 2005. Spatial variation of soil enzyme activities and microbial functional diversity in temperate alley cropping systems. Biology and Fertility of Soils 42, 129-136.

Murugan, R., Beggi, F., Prabakaran, N., Maqsood, S., Joerensen, R. G., 2020. Changes in plant community and soil ecological indicators in response to Prosopis juliflora and Acacia mearnsii invasion and removal in two biodiversity hotspots in Southern India. Soil Ecology Letters 2, 61-71.

Nelson, D.W., Sommers, L.E., 1996. Total carbon, organic carbon, and organic matter. Soil Science Society of America Book Series. Methods of Soil Analysis Part 3- Chemical Methods 5, 961-1010. Nelson, P.W., 2005. The Terrestrial Natural Communities of Missouri. Jefferson City, MO. Missouri Department of Natural Resources. $550 \mathrm{p}$

Newbold, C., Knapp, B.O., Pile, L.S., 2020. Are we close enough? Comparing prairie reconstruction chronosequences to remnants following two site preparation methods in Missouri, U.S.A. Restoration Ecology 28, 358-368.

Niu, H.B., Liu, W.X., Wan, F.H., Liu, B., 2007. An invasive aster (Ageratina adenophora) invades and dominates forest understories in China: altered soil microbial communities facilitate the invader and inhibit natives. Plant and Soil 294, 73-85.

Ohno, T., Doolan, K., Zibilske, L.M., Liebman, M., Gallandt, E.R., Berube, C., 2002. Phytotoxic effects of red clover amended soils on wild mustard seedling growth. Agriculture, Ecosystems \& Environment 78, 187-192.

Rosenzweig, S.T., Carson, M.A., Baer, S.G., Blair, J.M., 2016. Changes in soil properties, microbial biomass, and fluxes of $C$ and $\mathrm{N}$ in soil following post-agricultural grassland restoration. Applied Soil Ecology 100, 186-194.

Schradin, K., Cipollini, D., 2012. The sign and strength of plant-soil feedback for the invasive shrub, Lonicera maackii, varies in different soils. Forests 3, 903-922.

Tekiela, D.R., Barney, J.N., 2017. Invasion shadows: the accumulation and loss of ecological impacts from an invasive plant. Invasive Plant Science and Management 10, 1-8.

Thiele-Bruhn, S., Bloem, J., de Vries, F.T., Kalbitz, K., Wagg, C., 2012. Linking soil biodiversity and agricultural soil management. Current Opinion in Environmental Sustainability 4, 523-528.

Unger, I.M., Goyne, K.W., Kremer, R.J., Kennedy, A.C., 2012. Microbial community diversity in agroforestry and grass vegetative filter strips. Agroforestry Systems 87, 395-402.

United State Department of Agriculture, Natural Resources Con- 
servation Service. 2006. Land Resource Regions and Major Land Resource Areas of the United States, the Caribbean, and the Pacific Basin. U.S. Department of Agriculture Handbook 296.

Waller, L.P., Allen, W.J., Barratt, B.I.P., Condron, L.M., França, F.M., Hunt, J.E., Koele, N., Orwin, K.H., Steel, G.S., Tylianakis, J.M., Wakelin, S.A., Dickie, I.A., 2020. Biotic interactions drive ecosystem responses to exotic plant invaders. Science 368 ,
967-972.

Wolfe, B.E., Klironomos, J.N., 2005. Breaking new ground: Soil communities and exotic plant invasion. Bioscience 55, 477-487. Yannarell, A.C., Busby, R.R., Denight, M.L., Gebhart, D.L., Taylor, S. J., 2011. Soil bacteria and fungi respond on different spatial scales to invasion by the legume Lespedeza cuneata. Frontiers in Microbiology 2, 127. 